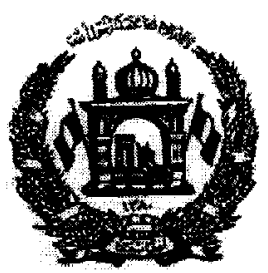

Transitional Islamic Sate of Afghanistan

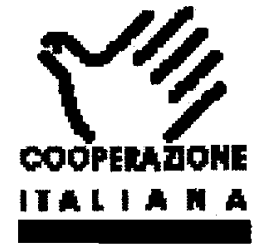

Italian Cooperation

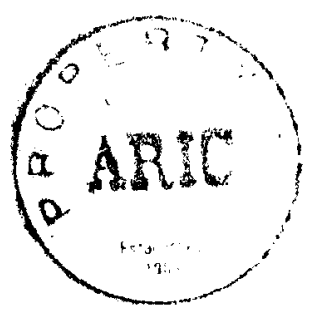

\title{
THE COMPREHENSIVE NATIONAL DISABILITY POLICY IN AFGHANISTAN
}

\author{
SUBMITTED TO MINISTER OF MARTYRS AND DISABLED \\ KABUL.
}

OCTOBER, 2003 


\section{TABLE OF CONTENTS}

Acknowledgements

Executive Summary

Chapter One: Introduction

Chapter Two:

Situational Analysis

Chapter Three:

National and International Context

Chapter Four:

Policy Guidelines on Disability

Chapter Five:

Policy Implementation

Chapter Six:

Policy Monitoring

Recommendations

References

Appendixes 


\section{ACKNOWLEDGEMENTS}

This Comprehensive National Disability Policy has been developed in collaborative manner by all stakeholders including primarily disabled people organizations and self help groups; disability NGOs both national and international; major line ministries including Ministry of Education, Ministry of Public Health, Ministry of Labor and Social Affairs, Ministry of Women Affairs, and Ministry of Martyrs and Disabled (MMD); related UN agencies including UNOPS/CDAP, WHO, ILO, UNICEF, and UNHCR; National Constitution Commission; and President Office.

The process was very much participatory until the production of this final document. It is important that this participatory approach continues for the future implementation of this policy and its proper integration into wider government development programs. As principal government agency, MMD will take this policy document and advocate and promote its proper discussion and endorsement by the Government of President Karzai and the National Constitution Commission.

We very much appreciate all the efforts invested in the production of this final policy, notably the commitment of disabled Afghans throughout the process as well as the technical support and guidance from several international experts in Afghanistan as well as overseas (see appendix of experts). MMD is also thankful for the financial support provided by the ISESCO and the Italian Government through the Italian Cooperation, Kabul respectively for sponsoring two workshops on disability policy. Equally, we are grateful for the technical support from UNESCAP which included a mission to Kabul by Ms Kay Nagata to assist in the production of this policy. Finally, we appreciate the facilitation role including the writing up of this policy document by Dr Majid Turmusani, Chief Policy Advisor at MMD.

This final document will be published with generous support from the Italian Government through the Italian Cooperation. It will also be displayed on the UNESCAP website as well as MMD website.

A

Wardak,

Minister

Domenico Giorgi

Disabled

of

Martyrs

and

Ambassador of Italy

Transitional Islamic State of Afghanistan.

Kabul. 


\section{Background}

This policy comes at a strategic point in time while the international community, notably UNAMA and the Transitional Government of Afghanistan are both setting up foundations for democracy in the country in preparation for the general election in summer of next year. Furthermore, the National Constitution is being drafted and it is important to include impairment and disability concerns in its text under the National Development Framework. The Constitution of Afghanistan provides the overall framework for developing a national policy on disability as it includes reference to fundamental human rights and freedoms.

The goal of this national policy is to promote the goals of an inclusive, barrier-free and rights based society for persons with disabling impairment in Afghanistan, as a set of policy directions. Also it is to protect and promote the rights and dignity of disabled people within the framework of a new Constitution. Accordingly, disabled Afghans are entitled to the enjoyment of the full range of civil and political, and socio-economic and cultural rights embodied in the Afghan Constitution (to be adopted by December 2003) and international human rights instruments (such as CEDAW, CRC, etc.) without discrimination against them at all.

The policy sets out an ultimate goal and a set of targets for the Government in partnership with civil society, including grass-roots organizations and community organizations, such as self-help groups of persons with disabilities, parents' associations, Islamic organizations and non- governmental organizations, the private sector, social groups and professional associations to address the existing barriers that exclude disabled people for the purpose of their integration. It is expected that the initial policy will lead to a more detailed and prioritized plan of action that need to be developed in order to achieve the ultimate objectives of this policy. A set of national legislatives may be needed to be adopted, based on this policy, in the near future.

The initial policy will also provide only a very broad framework within which to address the rights of disabled people under an each sectoral law, particularly the most vulnerable groups including young disabled children, women with disabilities and disabled refuges/displaced.

\section{Key policy areas}

This policy targets the disabled person as an individual and as part of society and therefore deals with all aspects of life. However, some key areas have been identified which need special attention based on the perceived needs and priorities of disabled Afghans. These include supporting disabled people's organizations, especially supporting women groups; raising awareness to educate and change public attitudes towards disabled people; prevention, early intervention and rehabilitation including health care and therapeutic aids; the development of guidelines for accessible environment and facilities, including access to information; education for all; accessible vocational training programmes and facilities; and an affirmative action plan to ensure that disabled people have equality of opportunity in employment options including sheltered employment.

Further, the inclusion of disabled people into society requires physical and programmatic access to cultural and recreational activities including sports, as well as access to social welfare, accessible housing and transport. It is important to promote the above as well as strengthen the position on Sign Language for deaf people and have information converted into Braille and in large prints for blind and partially sighted people respectively. 
Therefore, human resource development is necessary and a priority. Training will be given to personnel involved in the planning and provision of services for disabled people. The Government in coordination with the National Disability Commission (NDC) will take the lead role into the collection and dissemination of information as well as research into the needs of disabled people.

In implementing this Comprehensive National Policy on Disability, the Ministry of Martyrs and Disabled (MMD) will take the lead role for the coordination of national programmes. Designated ministries have been assigned special roles and responsibilities to implement this policy. The MMD and related government agencies will work closely with national and international organization including disability organizations to realize this policy. The MMD and NDC will collaborate together with other agencies notably organizations of disabled people for the monitoring of the implementation of this policy.

To co-ordinate this activity, the National Disability Commission should be activated and linked with the Office of the Deputy President for Constitutional Commission. The National Disability Commission will work together with, and parallel to the various state bodies and departments in order to further the development of a disability friendly environment. It will maintain close working links with the NGO sector.

\section{The vision of this policy}

The vision of this policy is to create a barrier free society for all based on the principles of participation, integration and the equalization of opportunities, defined by the United Nations in their World Programme of Action concerning Disabled Persons; the Standard Rules for the Equalization of Opportunities for Disabled Persons; The Biwako Millennium Framework for Action towards an Inclusive, Barrier-free and Rights-based Society for Persons with Disabilities in the Asia and Pacific region and the on going elaboration for the International Convention to Protect and Promote the Rights of Disabled Persons. In doing so, the Government of Afghanistan gives priority to enable disabled people to take charge of their lives by removing barriers which deter them from full participation in society.

Vision 1 - The UN Standard Rules for the Equalization of Opportunities for Persons with Disabilities.

Guided by the deliberations in the General Assembly, the Economic and Social Council, in 1990, agreed to an international disability instrument and authorized the Commission for Social Development to consider the establishment of an ad hoc open-ended working group of government experts, to elaborate standard rules on the equalization of opportunities for disabled children, youth and adults, in close collaboration with the specialized agencies, other intergovernmental bodies and non-governmental organizations, especially organizations of disabled people. The Council also requested the Commission to finalize the text of those rules for consideration in 1993 and for submission to the General Assembly at its forty-eighth session.

Although the Rules are not compulsory, they are regarded as international customary rules under international law. These rules imply a strong moral and political commitment on behalf of States to take action for the equalization of opportunities for persons with disabilities. The Rules offer an instrument for policy-making and action to persons with disabilities and their organizations. It also offers a framework for the international collaboration in the field of 
disability.

The purpose of the Rules is to ensure that all disabled people in their respected societies exercise the same rights and obligations as others through the removal of various disabling barriers and maximizing full opportunity for participation. Persons with disabilities and theil organizations should play an active role as partners in this process.

The rules pay special attention towards groups such as women, children, the elderly, the poor migrant workers, persons multiple disabilities, indigenous people and ethnic minorities. Ir addition, there are a large number of refugees with disabilities who have special needs requiring attention.

\section{Vision 2 - Biwako Millennium Framework (BMF)}

The ESCAP adopted Biwako Millennium Framework (BMF) for Action towards an Inclusive. Barrier-free and Rights-based Society for Persons with Disabilities in the Asia and Pacific region. An "inclusive" society means a society for all, and a "barrier-free" society means $\varepsilon$ society free from physical, environmental and attitudinal barriers, as well as socio-economic and cultural barriers, including the rights to development.

The BMF encourages Governments to actively implement the paradigm shift from a charity. based approach to a rights-based approach to the development of persons with disabilities anc to move towards the human rights perspective, especially the perspective of the rights tc development for persons with disabilities, bearing in mind General Assembly resolution 56/16ع of 19 December 2001 on a comprehensive and integral international convention to promote and protect the rights and dignity of persons with disabilities.

Complying with the BMF, "Afghanistan will be an inclusive and barrier-free society where disabled people can live in a society that recognizes and highly values of our own lives and dignity, and constantly enhances the process of full participation of all citizens, women and men, the disabled and non-disabled, the young and the old".

Vision 3 - International Convention on the Rights of Persons with Disabilities

The Government of Afghanistan, in collaboration with the civil society and other stakeholders and particularly with self-help groups of disabled people, shall support for the work of the Ac Hoc Committee, through the Working Group, to consider a proposal for a comprehensive anc integral international convention to promote and protect the rights and dignity of persons witr disabilities in the current process of elaboration of the international convention, and shal encourage and facilitate the full participation of a wide range of disability groups in the country from all regions in contributing to the work of the Working Group. The Government shal contribute to regional and international meetings/seminars on the elaboration of the Convention text, ensuring the full participation of Afghan disabled delegates in sucr meetings/seminars. The Afghani delegation to the Ad Hoc committee should include at leasi one expert with disability and one NGO representative.

The Government shall include persons with disabilities and their organizations, in the procedures at the national, regional and international levels, concerning the drafting anc adoption of the Convention, which by passing will ensure a strong consumer-influencec monitoring mechanism on the rights and obligations of persons with disabilities in the country.

Along with efforts towards the convention, "a new Afghanistan society will implement the paradigm shift from $\varepsilon$ 
charity -based approach to a rights-based approach to the empowerment of persons with disabilities and to move towards the human rights perspective, particularly the perspective of the rights to development for persons witt disabilities".

\section{CHAPTER ONE}

\section{INTRODUCTION}

Planning for the purpose of formulating disability policy and subsequent provisions requires valid data which can be collected through various research methods and assessment studies. In Afghanistan there is little reliable data on disability issues including the number of those witr impairments. Estimates indicate $4 \%$ of the population to be disabled which means that there are approximately 800.000 people who are disabled in Afghanistan. Many believe, howevel that the number of disabled people is much higher than that considering the long years of wal and continued active mine fields in the country.

The long year of political and armed conflict in Afghanistan has led to disability being depictec as a war issue and therefore, much attention has been given to war veterans at the expenses of other disabled people. The emphasis on war related injuries meant the majority of provisions were for physically impaired people and a medical professional approach tc disability. This has perpetuated the passivity of disabled people and their families and pushec them into the margins of poverty and social exclusion.

Disability in Afghanistan has been linked with the issue of martyrdom. War injured people have been regarded as disabled needing various services. The Ministry of Martyrs anc Disabled has been tasked with responsibility to cater for the needs of all disabled people. However, much emphasis is still being given to war disabled due to political reasons. The needs of other disabled people have been catered for by a number of active internationa organizations who supported disability sector over the past number of years. This includes International Committee for Red Cross (ICRC), International Assistance Mission (IAM) SERVE, and others. More recently other stakeholders got involved in supporting disability ir Afghanistan including local organizations such as Afghan Amputees Bicyclist for Rehabilitatior and Recreation (AABRAR) and Hearing Impaired Foundation for Afghan (HIFA).

Across the world disabled peoples' organizations have advocated disability as a human rights issue in accordance with the social model of disability which calls for societal anc environmental changes to accommodate the needs of disabled people. The goal must be the rights of disabled people to play a full, participatory role in society. This changing perspective is supported by the international community and now being materialized in a proposed drafl convention to protect and promote the rights of disabled people by UNESCAP.

This international thinking towards a human rights approach to disability has led MMD tc engage with other partners in a process of advocacy for full participation and equality of opportunities for disabled people. The process takes place within the context of reconstructior and establishment of provisional institutions of self-government with commitment for nationa policy development led by the development of the National Constitution.

A Task Force on Disability was established in February 2003 with the primary task of 
developing a comprehensive disability strategy for Afghanistan, in line with the UN Standard Rules on the Equalization of Opportunities for People with Disabilities and other international efforts notably the UNESCAP proposed convention on disability. This Task Force includes representatives of all stakeholders including disabled people and their organizations. In this sense, disabled people were given a voice in policy planning to ensure that their needs are taken into account whenever policy is being formulated.

The Task Force has identified a number of priority areas for policy action including education, employment and rehabilitation with a strong emphasis on following systematic approach to policy planning based on disability research practices. Specialist working groups were subsequently set up to coordinate and facilitate the production of policy documents for these three groups. These groups were the main mechanism for the development of disability policy. Various groups were facilitated by a lead agency and where possible they conducted extensive consultations and research on the situation of disabled Afghans in their respected areas of expertise.

According to the global perspective of needs, the following areas have been identified for disability policy action. These include the need for prevention, health care, rehabilitation, public education, barrier free access, transport, communications, data collection and research, education, employment, human resource development, social welfare and community development, social security, housing and sport and recreation.

Although all these above are important for the inclusion of disables people into society, only eight of them were considered as priority key policy for disability in Afghanistan and thus included in the guidelines for Comprehensive National Disability Policy. This includes support for Disabled People Organizations (DPOs), women with disability, awareness raising, rehabilitation, education, employment, accessibility, and national coordination. This Comprehensive Disability Policy has developed policy objectives, strategies and mechanisms for each of these areas.

The vision proposed in this Comprehensive National Disability Policy is a society for all. This means the integration of disability issues in all government development strategies, planning and programmes. There must be an integrated and coordinated management system for planning, implementation and monitoring at all spheres of government. For complementing the process, there must be capacity building and wide public education.

Finally, in order to ensure that legislation is effective and policy is implemented, research and monitoring are essential. Transformation must involve practical change at every level of society.

\section{Disability as a human rights and development issue}

Until recently, disability was regarded as an issue of care/cure with the responsibility of supporting disabled people falling on the family. State intervention was often channeled through welfare institutions with little commitment to addressing disability in other areas of government responsibility, such as access to health care, education, training, employment, and wider participation. The dependency which this welfare model created disempowered disabled people, and isolated them from the mainstream of society.

Disability as a human rights and development issue, in contrast, emphasizes equal 
opportunities for all. This is the process through which the various systems of society and the environment are made available and accessible to all citizens. As part of the process of equal opportunities, provision should be made to assist them to assume a more complete responsibility as members of society. They should receive the support they need within the ordinary structures of society in areas such as education, health, employment and social services

The principle of equal rights implies that the needs of each and every individual are of equal importance, and that those needs must be made the basis when planning and making policies. Furthermore, all resources must be employed in such a way as to ensure that every individual has equal opportunity for participation.

This is in accordance with various international statements including United Nations Declarations on Human Rights. Thus, the Government of Afghanistan accepts the principles of participation, integration and equalization of opportunities, defined in the UN's World Programme of Action Concerning Disabled Persons (WPACDP) and The Standard Rules on the Equalization of Opportunities for Persons with Disabilities. The Government of Afghanistan also accepts the principles of rights based approach to disability in the proposed international convention on disability as well as the principles of society for all cited in the Biwako Millennium Framework.

These principles shall serve as leading guidelines and also form the basis for the implementation of the Comprehensive National Policy on Disability. These principles are also stated in the Declaration on the Year of Disabled Persons (1981). The National Policy shall also represent the policy referred to in Article 2 of ILO Convention No. 159 on the Vocational Rehabilitation and Employment of Disabled Persons.

The Government further accepts the principles incorporated within the following declarations which proclaimed the necessity of protecting the rights and assuring the welfare and rehabilitation of the physically and mentally disadvantaged: Universal Declaration of Human Rights, the International Covenants of Human Rights, the Declaration of the Rights of the Child, the Declaration on the rights of Mentally Retarded Persons, and the Declaration on Social Progress and Development.

\section{CHAPTER TWO}

\section{SITUATIONAL ANALYSIS}

\section{Prevalence of disability in Afghanistan}

There is a serious lack of reliable data on disability and disabled people in Afghanistan. The fact that disability has been regarded as a war issue led to one single agency responsible for their welfare. This hindered the smooth integration of disability issues into mainstream government programs including statistics and surveys needed for planning such programs.

No accurate or reliable statistics exist on the number of disabled people in Afghanistan. UNDP and Central Statistics Services estimate $5.2 \%$ of world population to be disabled (UNDP, 1991). This is ranged from $7.7 \%$ in developed world and $4.5 \%$ in developing 
countries. However, this might not apply to Afghanistan given the high number of disabilities caused by war and its after math.

A number of uncoordinated sample surveys have been conducted on disability in Afghanistan. Their results show different prevalence of disability ranging between $1 \%$ for disability among children (CDC, 2003) and $4 \%$ according to national survey in progress by MMD. Considering that disability does not only affect the impaired individual but also their family and wider community, we can argue that there is much more than $4 \%$ disabled people in Afghanistan.

The different estimates of disabled people in Afghanistan are mainly due to using different definitions to who is considered disabled. Negative attitudes towards people with impairment together with poor infrastructure make it difficult to identify and survey all those with disabilities, in addition to the problem of the lack of resources to conduct proper research (Coleridge 2001).

\section{Disability and exclusion}

The overwhelming majority of disabled Afghans and their families experience social and economic deprivation and many of their basic rights are denied by institutional structure. Poverty and unemployment are key factors for perpetuating the exclusion of disabled people, but at the same time both can be a result of disability. The political and economic inequality compounded by negative social attitudes has perpetuated a stereotype of disabled people as dependent and drain on public resources. This has led to institutional discrimination against them primarily by denying them access to services because of many disabling barriers. Legislations that fail to protect the rights of disabled people also lead to discrimination.

There are certain sectors which experience a higher level of exclusion and this includes. people with severe intellectual - mental and psychiatric - or multiple disability, elderly people, rural disabled, those displaced by violence, the war disabled and disabled refugees. Given this widespread exclusion of minority groups, it could be concluded in line with Nagata (2003) that women and children are severely affected by this situation.

\section{Causes of disability}

There are many factors which causes impairment and lead people to become disabled. The most notable in the context of Afghanistan are war and landmine issues, given the long years of armed and political conflict in the country. However, it should be recognized that nature has been harsh on this already deprived region multiple years of drought and poverty left many people with impairments, especially malnutrition. Increasing numbers of road and other accidents are also among causes of impairments in Afghanistan.

The lack of awareness on disability prevention led to many new cases of impairment which could be avoided. Further, the poor medical infrastructure meant that many treatable cases have to develop into permanent impairments.

Regarding disability causes among youths, the 2003 Italian Cooperation survey in 65 schools of Kabul showed the importance of congenital disability (31\%), compared to other causes, including war injuries (16\%). This result highlight the very low level of antenatal care and inadequate treatment of infectious diseases, together with poor awareness of planning familial issues and the increased genetic risk made by traditional use of marriage inside the family (between cousins). 
Despite the mass production of drugs in Afghanistan, until recently there has been little attention given to this issue and how it relates to disability. Drugs issues in Afghanistan deserve a closer look with proper research. Poppy producers have taken up this dangerous farming as a career. Many of those farmers are not only involved in the production of this deadly drug but are also users of it. The lengthy use and overdose of poppy derivatives surely lead to different kinds of impairments and disabilities.

Finally, other causes of disabilities are environmental factors including epidemics; accidents; natural disasters; and pollutions by poisoning and toxic waste all lead to causing impairments. Inaccessible environments in turn lead to creating new disabilities and perpetuating existing ones.

\section{Approaches to disability}

Recent debate on disability has witnessed extensive discussion on various approaches to understanding and dealing with disability issues, notably, discussion on two prominent approaches which are the medical and social model of disability. Understanding the way in which disability is being constructed will help alleviate the problems associated with it and resolve them.

Traditionally and until recently, disability has been regarded as personal problem requiring modification at the level of individual. Care or cure course of action are normally proposed by professionals. The political implication of this model on policy and provision is that society has little responsibility to provide for the diverse needs of disabled people and when it does it focuses on changing the individual to suit the surrounding environment. In brief, this model gives society reason to deny services for disabled people.

The social model which informs this policy on disability, in contrast, views disability as a societal issue produced by social values and culture. It is based on the human rights of disabled people and calls for equal opportunity and full participation of all citizens in society. This model focuses on removing the disabling barriers and trusts in the full abilities and potentials of disabled people. Further, this model calls for equal and active participation of disabled people in the development process. Central to the concept of the social model is the principle of self representation by disabled people groups, thus the need to support these groups and empower them.

The shift from the medical model of disability into the social and human rights perspective is also reflected in current definitions of disability. Disability is defined as the outcome of the interaction between peoples with impairments and the environmental and attitudinal barriers they encounter in daily life in accordance with the new WHO's International Classification of Functioning, Disability and Health (WHO, 2001).

Definitions have political implications on the way in which persons with disabilities are viewed by society and by themselves. They also influence the type of provision made to meet the needs of persons with disability. For this reason, the social model defines disability as social issue and looks at it in relation to disabling barriers. In implementing this policy, it is the social model that is more relevant to the lives of disabled people, although their medical needs should not be neglected. The various medical and developmental needs of disabled people should be catered for through an improved infrastructure of service provision. 


\section{Existing structure of disability}

Although disability services in Afghanistan are very basic and focus primarily on the war disabled, there is a unique advantage for disabled Afghans as they have an independent government ministry set up to serve disabled people among other minority groups.

The Transitional Islamic State of Afghanistan has paid special attention to minority issues including disabled people. The government of President Karzai through the National Development Framework (NDF) has relentlessly supported the development of disability national institutions, namely the Ministry of Martyrs and Disabled (MMD). This strong commitment towards disability issues has never changed in regarding disability as a development issue with focus on human rights.

Created originally to cater for the needs of Martyrs and war disabled, the Ministry of Martyrs and Disabled (MMD) is currently the principal government agency responsible for disability coordination, advocacy and information dissemination in Afghanistan. MMD is structured to develop and deliver a comprehensive package of services to the disabled community in order to enable effective participation and economic life. Currently, MMD is taking the leading role in the development of a Comprehensive National Disability Policy and strategy so that the needs of disabled people are better served and their rights are ensured.

The long years of war in Afghanistan has literally affected every aspect of life, but disabled people were much more affected than others due to their vulnerable position in society. Widespread poverty, drought and natural disasters have resulted in many destitute people with impairment who need immediate attention and care. MMD is facing tremendous challenges in meeting the various and increasing needs and demands of disabled citizens, especially women and children with disability.

The situation of disabled people is generally poor and MMD sources indicate that there are over one million people in Afghanistan who have a disability. While hundred of thousands of Afghans were made disabled by war and landmines, many more have acquired impairments from birth, accidents or malnutrition and preventable diseases. There are large numbers of people who were psychologically traumatized who receive few services if any. Equally true there are many people with learning disabilities, mental impairments and multiple disabilities that hardly receive any attention from the international community and disability organizations working in Afghanistan.

The mapping tools for service providers showed the Eastern and Southern Zones amongst areas, which need further disability interventions. However, other areas of Afghanistan have also been identified as priority areas for services as zero support exists in such places (i.e. Nuristan, and Wakhan). Other areas were also identified as very underserved including Khost and Paktika, Uruzgan, Ghor, Bamyan, Sar Pul, Nimroz, and Faryab. The mapping also showed more services directed towards physically impaired people than those with hearing and visual impairments. Relatively, the majority people with impairments in remote areas are still not reached including physically disabled people.

The international community has greatly helped to advance the cause of disabled people through various initiatives notably the UN Comprehensive Disabled Afghan Programme under UNOPS who also supported the initial stages of this policy development, International 
Committee for Red Cross, International Assistance Mission, and SERVE. Having said that, there are also a number of promising local initiatives which provide quality services for disabled Afghans. This includes Afghans Amputees Bicycle for Rehabilitation and Recreation (AABRAR), and the Hearing Impaired Foundation for Afghanistan (HIFA) and the National Association of Disabled Afghans (NADA).

Although there is no national umbrella organization of disabled people in Afghanistan, a growing number of disabled people organizations and groups are now emerging although at a very slow pace. This includes the Afghan National Association of the Deaf (ANAD), the Afghan National Association of the Blind (ANAB), the National Association of Disabled Women in Afghanistan (NADWA), Disabled Shura of Afghanistan (DSA). The latter is a war veteran association and comprises only disabled men. All these above organizations are located in the capital Kabul and their main focus is to advocate the rights of disabled people and liaise between disabled people and service providers including policy makers. More attention will have to be given to disabled people groups in the regions so that the above national organizations become truly representative of the whole disabled target population.

Disabled people in fact, have great potential and they can be valuable resources in the rebuilding process of Afghanistan. Education and training are key skills that will assist disabled Afghans to become economically independent and active members in society. The Government and the international community including donors and the private sector, in the future should collaborate together to ensure that all disabled people have equal access to societal provisions.

The policy of the Ministry of Martyrs and Disabled (MMD) is to encourage education, training, and economic integration of disabled people by creating an environment that allows full participation and leads to empowerment. Disabled people organizations play central role in their own empowerment process. It is important that other ministries and organizations also take initiative and integrate disabled people within their mainstream services in coordinated manner.

\section{The National Disability Commission (NDC).}

The responsibility of serving disabled people was always given to MMD. Since disability was regarded a war issue, MMD served those disabled by war and the families of martyrs. Other disabled people have been served by International Non Governmental Organizations (INGOs) and more recently local Non Governmental Organizations (NGOs) as mentioned earlier. Services remain uncoordinated and ineffective reaching only a small proportion of target community.

Many attempts have been made to set up a coordination mechanism for the disability sector in Afghanistan and provide reliable data for planning. The National Disability Commission (NDC) was established as a result to coordinate disability sector and plan necessary policies. In theory, NDC should serve as an advisory body for the government on disability matters including coordination and supervision of the implementation of policies; ensuring effective monitoring; ensuring the commitment of resources; and developing effective reporting strategies. NDC in practice however, remain ineffective mechanism until now, mainly due to the poor involvement of disabled people and their organizations in its structure. There is therefore, a need for reforming its overall structure including its membership and their functions. 
The cross cutting nature of disability requires inter-agency coordinated effort for effective service delivery. For this reason there is justification for the existing National Disability Commission being attached to Deputy President for Constitutional Commission. This will help a smooth integration of disability issues in all governmental programs under the National Development Framework with budget allocation from the National Development Budget (NDB).

\section{CHAPTER THREE}

\section{NATIONAL AND INTERNATIONAL CONTEXT}

\section{Disability agenda in Afghanistan}

Afghanistan is undergoing a complete process of reconstruction and rebuilding of its social and economic resources. The long years of war have resulted in total destruction of the infrastructure of the country as well as the destruction of people's self confidence for peaceful living in this region. Further, nature has been harsh to this already deprived region and years of drought and resulting poverty have been major causes of impairment in Afghanistan, especially those relating to malnutrition. According to the United Nations, there are between 9 - 10 million land mines in the country and estimates indicate more than $10 \%$ of the total population being disabled.

The continued political conflict in the country has resulted in limited services being available for war veterans and other disabled people. This conflict has always prevented the healthy development of civilian life including law and order. Laws have often been created to meet the needs of the specific war and emergency situation, including laws for the families of martyrs, war disabled and disabled people in general. Disability therefore was depicted and regarded as a war issue and accommodation was made within an emergency context until recently.

For example, Afghanistan's earlier Constitutions of 1923 and 1963 have no reference to disabled people at all, nor to the issue of vulnerable groups' altogether. This is due to a relatively peaceful era in Afghanistan's history in early and mid of last century. The first mention of disabled people in legal terms came in Afghanistan's constitution of 1987 and it was repeated again in constitution of 1990 . In both Constitutions, Chapter Three highlights the obligations and duties of Afghans citizens as well as their basic human rights and freedoms. Article Fifty Seven of both Constitutions state the rights of all Afghans for health and social security. Specifically, this article emphases the improvement of material welfare for the aged, war and work disabled and the dependents of martyrs.

The Sectoral Laws, for the first time in Afghanistan's history made reference to disabled people in Laws of 1980 and 1987. Given the on-going armed conflict in the country, not surprisingly, these laws confined and defined disability within the category of war related injuries and called for material provisions for them including medical, financial, and economic reintegration (Afghan Constitution: Law 1980/Article 3 and 4 and Law 1987/article 57).

However, there are many global forces influencing the on-going process of rebuilding 
Afghanistan including the international disability standards and laws, as well as the selfawareness of the local disability movement itself. The violations of human rights including disabled people rights have provided impetus for measures to confront discrimination practices against disabled people. Together these necessitate special laws to ensure the rights of disabled people and their equal access to services.

These are amongst several other development challenges facing the country and affect the disability sector as well as the future peace of the country. This includes primarily the promotion of -security and creation of a social consensus on human rights, dignity and the value of life through establishing the rule of law. This may prevent impairments caused by war and violence.

Nevertheless, there are many signs of hope for the redevelopment of a peaceful agenda in Afghanistan including law and order. For example, the progress made on the political frontbringing the Loya Jirga process on track and moving steadily towards a smooth transition from Transitional Authority to a fully elected government in June 2004 is promising. Work has also been completed on the Final Draft National Constitution.

Meanwhile, there is on-going effort to develop policies for disabled people with participations of all stakeholders including disabled users of services. An example is this Comprehensive National Disability Policy. This policy document sets the scene for future sectoral laws on disability developed by concerned line ministries. Other sectoral policies targeting disabled people however are in progress by line ministries.

The Ministry of Martyrs and Disabled (MMD) is leading a number of other line Ministries including Ministry of Public Health (MoPH), Ministry of Education (MoE), and Ministry of Labour and Social Affairs (MoLSA) in developing internal policies targeting disabled people. It is noted, however, that these policies are still limited in their scope focusing only on certain categories of disabled people. Overall, disability issues are not being given a full priority in the respected programs developed by various ministries. For example, the Interim Health Strategy of Ministry of Public Health 2002-2003, states the importance of supporting disabled people. Disability in this policy document has been included within wider discussion of vulnerable groups such as homeless, women and displaced people. The Ministry of Public Health after consultations with various stakeholders, concluded that mental health and disability issues do not constitute a priority for the Basic Package of Health Service in Afghanistan 'at this stage'. Although MoPH recognizes the significant proportion of disabled people in the country, the availability of resources has unfortunately determined their priorities and influenced overall health planning.

Education policy in Afghanistan, on the other hand, has no reference to special education of disabled people including a higher education. In late 2002, the Ministry of Education, supported by UNICEF, drafted the Policy for the Rehabilitation and Development of Education in Afghanistan. This policy document in its First Item states a compulsory primary education for all regardless of gender, ethnicity, language or religion. There was no reference to compulsory education for disabled children, unfortunately. Instead, there was indirect emphasis on the prevention of impairment by various educational strategies. This includes awareness raising of the negative consequences of terrorism, drug addiction, war/conflict and discrimination, all of which may be considered causes of impairment. No educational intervention for disabled children was yet mentioned despite the large number of children with special needs. A recent survey on the situation of disabled children in education in Kabul 
found that only $1.11 \%$ of total school children were disabled and have access to schooling of any kind (Italian Cooperation, 2003).

As for a specific policy on employment, the Ministry of Labour and Social Affairs have developed some guidelines for the employment of disabled people. The long years of war with large numbers of war veterans have necessitated special provisions for war disabled. These regulations however have mainly focused on the war disabled and other types of disabilities were as a result excluded.

A recent survey conducted by Ministry of Labour and Social Affairs and International Rescue Committee (IRC) has found very high level of unemployment among disabled people estimated at $84 \%$ (Agnew, 2003). The same study has found that services for disabled population are mainly centered in big cities, especially in the Kabul region. MLSA attempts to address this nation wide problem by developing special guidelines for the employment of disabled people. In their internal regulations for example, MLSA has recently emphasized the need for the vocational training of all disabled people as well as their need for welfare benefits and employment.

The most comprehensive policy position on disability was drafted in early 2003 as a result of a highly political situation created by disabled war veterans. The expressions of repeated dissatisfaction by the war disabled in Afghanistan has led the Ministry of Martyrs and Disabled to join efforts with three other ministries and propose a policy for protecting the rights of war disabled and families of martyrs. Those line Ministries included the Ministry of Transportation, the Ministry of Reconstruction, and the Ministry of Labour and Social Affairs.

In this joint policy statement, the MMD has been given a principal role for the registration, data collection and referral of war disabled to concerned line Ministries. The MMD was also tasked with the responsibility of employing disabled war veterans, an issue still under debate. This policy has also advocated financial benefits for war disabled and families of martyrs. Financial support has been determined for the above group ranging between 6-14 US\$ for war disabled and 11 US\$ for the family of a martyr. Additionally, the poorest of these families will receive wheat rations. Further, this policy proposal has also stated a quota of $2-3 \%$ for reserved employment of disabled people in public sector if they posses required abilities to hold the job in question. Finally, this policy stated free health care for war disabled as well as discounted air travel and land for housing cases with no ability for securing basic shelter.

In conclusion, work on the above disability policies is still under development and in its early stages. Existing sectoral policies and programs produced by line ministries remain scattered and uncoordinated focusing mainly on war disabled. This draws the attention to the urgent need for much emphasis be given to the rights of all disabled people as priority issue. There is a growing national and international support for including a number of paragraphs ensuring the rights of disabled people in all spheres of life in the recently drafted National Constitution. The MMD, after consultation with UNESCAP, has officially requested the National Constitution Commission in Afghanistan to include a number of paragraphs on comprehensive disability rights which are quoted from the Constitution of Timor Leste. The intention is to promote and protect the full range of rights for disabled people including their right for accessibility, education, employment, rehabilitation, and welfare support to name but few.

International context

http://www.disabilityafghanistan.org/finalpolicy.htm

$12 / 10 / 2004$ 
There are a number of international landmarks which greatly advanced the cause of disability worldwide. This includes the international year of disabled persons which led to the World Program of Action Concerning Disabled Persons (WPACPD). The purpose of this world action was to promote effective measures for the prevention of disability, rehabilitation and the realization of equal opportunities for persons with disabilities. This equalization of opportunities came out in full in the Standard Rules for Equal Opportunities for Persons with Disabilities in 1993.

The decade of disabled people 1993-2002 and 2003-2013 are also important time periods to ensure proper implementation of measures to protect the rights of disabled people.

At the regional level of Asia and Pacific, UN ESCAP adopted the resolution "Promoting an inclusive, barrier-free and rights-based society for people with disabilities in the Asian and Pacific region in the twenty-first century". The resolution also proclaimed the extension of the Asian and Pacific Decade of Disabled Persons, 1993-2002, for another decade, 2003-2012.

The new decade (2003-2012) will ensure the paradigm shift from a charity-based approach to a rights-based approach to protect the civil, cultural, economic, political and social rights of persons with disabilities.

Governments at the High-level Intergovernmental Meeting to Conclude the Asian and Pacific Decade of Disabled Persons 1993-2002, adopted the "Biwako Millennium Framework for Action towards an Inclusive, Barrier-free and Rights-based Society for Persons with Disabilities in Asian and the Pacific," as the regional policy guideline for the new decade.

The "Biwako Millennium Framework" outlines issues, action plans and strategies towards an inclusive, barrier-free and rights-based society for persons with disabilities. To pursue these targets and strategies, consultations with and involvement of civil society, and inter alia, selfhelp organizations and concerned NGOs are essential.

BMF has identified seven priority areas for action including supporting the development of self-help groups and organizations for disabled people and related family and parental associations; women with disabilities; early detection, intervention, rehabilitation and inclusive education; training and employment; access to built environments and public transport; access to information, communications, and assistive technologies; and poverty alleviation through capacity-building.

Further, the BMF details the targets, strategies, time frames and the supporting/monitoring mechanisms for an effective national policy on disability. This emphasis on the development of national policies on disability across the world is clearly stated in the UNESCAP proposed new international convention to promote and protect the rights of disabled people based on the BMF ideals of a barriers free society for all which Afghanistan fully support.

CHAPTER FOUR

\section{POLICY GUIDELINES ON DISABILITY}




\section{Background}

In October 2002, during the UNESCAP high level intergovernmental meeting, Afghanistan signed the resolution for the extension of Asian and Pacific Decade of Disabled Persons, 1993-2002, for another decade, 2003-2012. The same resolution has also adopted the Biwako Millennium Framework (BMF) for Action towards an Inclusive, Barrier-free and Rightsbased Society for Persons with Disabilities in Asian and the Pacific.

The BMF has encouraged all governments in the Asia Pacific region to develop a national policy on disability. After extensive consultations with international community including leading regional initiatives on disability policy, the Ministry of Martyrs and Disabled sought to use the BMF as guiding framework for developing its on going National Disability Policy with eight priority areas based on the BMF as listed below.

The on going policy development under the Task Force on Disability has produced policy guidelines on disability, but only in the three areas of education, employment and rehabilitation. It was recognized that the needs of disabled people go far beyond the three areas. For this reason, the BMF offers a more comprehensive framework for national policy on disability in Afghanistan. The Task Force on Disability has agreed on the use of the BMF framework, but collectively participants made modifications on the original BMF text to suit the Afghan context. The overarching goal, principles and vision of the BMF remain unchanged, though, focusing on the creation of society for all. The BMF guidelines are being integrated together with the above national produced guidelines to reach one unified policy.

This Comprehensive National Disability Policy include eight priority areas for policy action based on BMF as follow: support for disabled people organizations, women with disability, awareness raising, rehabilitation, education, employment, accessibility, and national coordination. This Comprehensive Disability Policy has developed policy key actions as well as strategies both of which are necessary for the development of specific mechanisms for effective implementation of each policy area.

\section{Vision: a society for all}

A 'Society For All' by definition means creating an inclusive environment where all citizens are valued regardless of their diverse situations. In such a society all people take active part in the development process including those with impairments. The concept of a society for all, encompassing human diversity and the development of all human potential, captures the spirit of the human rights instruments of the United Nations.

This Comprehensive National Disability Policy aims primarily at facilitating the integration of disability issues into government developmental strategies, planning and programmes. In so doing, this policy aims at highlighting the various needs of disabled people and the human rights approach to addressing such needs; identifying disabling barriers that create impairments and prevent disabled people from full participation and limit their ultimate inclusion in society; proposes strategies for removing such barriers including socio-economic, cultural and political strategies (i.e. legislations); and emphasizes the leading role of disabled people and their organizations in the process.

To achieve the above goal there is obviously the need for the development of capacity 
building strategies, particularly in terms of the coordination, implementation and monitoring of this policy. Since disability is cross cutting issue, this means interagency and coordinated efforts in addressing the various needs of disabled people with the principal coordinator role given to MMD. It has to be integrated into the national development plan with a budget allocation as being emphasized elsewhere in this document.

This policy also focuses on special target groups including women and children with disabilities, parents of children with disabilities, elderly people, rural disabled, people with mental and intellectual disabilities, those with severe and multiple disabilities, war disabled, and disabled refugees.

\section{Guidelines}

\section{Support the development of self-help groups and organizations for disabled people and related family and parental associations}

Disabled people are the most qualified to advocate for themselves and other disabled people. The quality of life of disabled people improves when they actively voice their concerns and participate in decision-making. Self-help organizations of disabled people are the best informed and most motivated to speak out on their own behalf concerning the formulation and implementation of appropriate disability policy, legislation and strategies, which in return will ensure their full participation in civil, political and socio-economic and cultural life and enable them to contribute to the development of their own communities. Self-help organizations provide an effective means through which collective capacity-building and empowerment of disabled people can be achieved, through strengthening their lobbying power to advocate with governmental and other civil society and their active participation in decision-making processes. The development of such groups will be enhanced with the formation of a partnership with the National Disability Commission and administrations in both central and local governments.

Disabled people have a right to participate in family and community decision making and community affairs at all levels including within the village, district administrations and national Government. Disabled people also have a right to participate in the private sector and all kind of civil society; including religious entities and other non-governmental organizations and members of these organizations must address how they can include disabled people.

Integrating disabled people in development strategies has economic and social benefits at all levels. Disabled people tend to be excluded from the process of planning and decisionmaking. In order to achieve equal participation, disabled people must play a vital role in the formulation of national policy on all kind of sectoral issues (e.g. health, education, transport, housing, etc.) that affect their lives directly. The family is at the center of Afghan community life, and family members including parents, particularly mothers, wives and grandparents are usually the most sustainable and only source of support and care for disabled people. They often need financial support in order to improve the living conditions and livelihood opportunities of the family. The important role that caregivers play in the community should be recognized. Care givers need support from the wider community for the important role they play. This may include the training and provision of information and equipment.

In brief, discussion by various stakeholders including disabled Afghans has pointed out the need for different kind of self help groups representing the interest of disabled people and their 
allies. Regional and local representation including representation on the Constitutional Commission was also recognized as important in the development of grass roots action for future disability movement in Afghanistan.

\section{Key actions}

- Awareness raising programmes to be developed by NDC and MMD targeting local administrations and aiming at raising the profile of disability issues highlighting the abilities of disabled people and the potential benefits of their self help groups to wider development process;

- Ministries, other government agencies and local governments to include disability in their policies, programmes and activities;

- The MMD takes leading role in supporting various self-help groups including regional initiatives;

- The MMD disseminates information to members of self-help groups;

- The MMD ensures the representation of disabled people, their families, government officials from various sectors, and other service providers on the National Disability Commission;

- The NDC and the MMD develop awareness raising programmes for local/village communities on disability rights issues;

- The NDC becomes the national forum and umbrella group for disability;

- Ministry of Public Health (MoPH) and MMD in consultation with other key stakeholders to develop information packs for care givers;

- The MoPH and the MMD agree on how to gather data on who is providing care for disabled people;

- Community health workers to be trained on how to monitor and record needs and share information with MMD.

\section{Women with disabilities}

Women and girls with disabilities are often exposed to poverty more than boys and men with disabilities and face discrimination within the family. Women and girls need to have equal access to health care, education, vocational training, employment and income generation opportunities, and to be included in social and community activities.

Women and girls with disabilities encounter all kinds of discrimination as they are exposed to greater risk of physical and sexual abuse and often are not given adequate sexual health and reproductive rights advice. These issues need to be addressed not only through this policy, but also through the broader context of gender mainstreaming and women in development policies and through a national council of women (upon formation). They should actively involve and include women and girls with disabilities and empower women and girls, at the 
grassroots level. Such policies must, in particular, assist families to gain an adequate income so they can meet the needs of their disabled children.

Introducing and enforcing legislation is of utmost importance to protect the most vulnerable, including disabled women. Legislation must focus on all forms of discrimination against disabled women and girls including sexual, physical and mental abuse, and the need to provide gender equal opportunities in education, health and employment.

One important strategy is to mainstream gender and disability into all government programmes, especially in the MMD and other line ministries. Further, support for the self employment of disabled women, including in the farming community is needed together with all kind of capacity building support including communication support where applicable. Supporting self help among disabled women is a priority.

\section{Key actions}

- The MMD in collaboration with the NDC to conduct national and community workshops on human rights and vulnerability of girls and women with disabilities;

- The MMD and the NDC to conduct training workshops for health, welfare and police on 'rights' of most vulnerable groups in remote communities against violence and possible abuse;

- The Ministry of Women's Affairs collaborates with the NDC and the MMD including disability in Gender and Development (GAD) programme;

- National Council on Women (to be formed) or an equivalent national NGO network includes disability of women and girls in their programmes.

\section{Prevention, early detection, intervention, and rehabilitation}

Young children with disabilities require access to early intervention services, including early detection and identification (within the first 5 years after birth). This process may be supplemented by support and training to parents and families to facilitate the maximum development of the full potential of their disabled children. Failure to provide early detection, identification and intervention to babies and young children with disabilities and support to their parents results in secondary disabling conditions limiting for the rest of life the children's capacity to enjoy educational opportunities. Subsequently it will increase health and welfare costs to the State in the long term. The provision of early intervention should be a combined effort of Education, Health, particularly the primary care workers, and the Ministry of Martyrs and the Disabled (Disability Officers).

Many of the causes of impairments and injuries are preventable through increasing level and quality of antenatal care, increasing women health education, developing safe living/work place environments, improving safety measures in the community, including road safety, which can decrease disabilities associated with traffic accidents. Similarly, improving immunization and eliminating malnutrition and iodine deficiencies and good awareness of balanced diet and other daily practices to improve health can also decrease the incidence of certain types of disabilities. For example, vaccination should be made compulsory. In brief, much focus should be placed on prevention, rather than cure using multidisciplinary approach 
with local leaders employed and other communication tools such as video cassette especially for intellectually impaired people.

Greater awareness needs to be created, particularly in remote communities of the country about how disabilities can be prevented through community health practices. One effective approach in rural areas is Community Based rehabilitation (CBR). CBR models developed in other low income countries such as Indonesia are closely linked to early intervention measures. CBR workers and primary health workers are trained in the early identification and referral of infants with disabilities in both rural and urban areas.

In the context of this policy, rehabilitation is defined in accordance with the Standard Rules. It concerns not only those with physical impairment but extends to people with visual impairments, those with hearing impairments and people with intellectual disability. There is need therefore, for specific provisions for each category of disability.

Provisions for people with physical disability for example, should include orthopedic rehabilitation centers; physiotherapy services; and orthopedic, assistive and mobility devices. These services should be close to a regional or provincial hospital with orthopedic surgical services so that the local population has easy access. They could be located ideally, in cities with medical teaching faculties such as in Kabul, Mazar, Heart, Kandahar and Jalalabad. Future services should provide for an expansion in orthotics as this is underserved.

All patients have the right to receive devices. Devices should be well-made, well-fitting, of local materials whenever possible and repairable locally. Appropriate technology should be standardized throughout the country. A mechanism for national standardized should be created with relevant experts in collaboration with $\mathrm{MOPH}$.

People with visual impairment on the other hand, require services including visual assessment, rehabilitation (orientation and mobility daily living skills, manual dexterity skills, communications skills, social skills and recreation), family and community integration, counseling and mobility devices including canes and guide dogs.

People with hearing impairments require services include hearing assessment provision and fitting of hearing aids, maintenance and repair of hearing aids and rehabilitation (communication skills, social skills and integration). Regional/provincial/district resources centers for hearing impaired could include research, training, and development of educational and other materials, special education for special cases.

Finally, people with intellectual impairments require services including assessment of the capacity of learning ability and level of development, daily living skills, social skills, manual dexterity skills, and social integration. Mental illness should be referred, if needed, including cases of epilepsy. Community-based approach to mental health is advantageous (i.e. education of the community on mental health issues, and how to support people with mental health problems and when to refer them).

Awareness-raising strategy on all the above issues is of prime importance. An officer should be appointed at MMD whose function and duty is to create awareness in society about persons with disabilities, their rights, their needs, their potential and their contribution to their community, by collecting and distributing information on the rights of disabled people and on available programmes and services, to persons with disabilities and their families. Specifically 
this will target medical professional, including community health workers, traditional birth attendants and community volunteers about the importance of prevention of disability and secondary disability thorough medical schools.

\section{Key actions}

- Ministry of Public Health (MoPH) to develop policy and strategy on early intervention priorities in collaboration with the MMD. This includes those with physical, visual, hearing and intellectual impairments;

- Ministry of Public Health (MoPH) increases the quality level and coverage of antenatal care services including the development of health education sessions on women health and pregnancy.

- MoPH to hold workshops on early intervention in the local communities for Health, Welfare and Education personnel;

- "Front line" health and education personnel keep accurate records on children with disability and other "at risk" children, from birth;

- Awareness programmes targeting community and employer should be developed. The Education of medical staff including disability awareness should be part of all medical and paramedical education;

- Resources committed to develop information packs for employers on work place safety;

- MMD and MOPH agree on information requirements and how it is collected;

- MOPH to collect data on needs for rehabilitation and assistive services throughout the country;

- MOPH to conduct policy and strategy review on integrating rehabilitation and assistive devices needs throughout the country;

- MOPH in collaboration with MMD to conduct awareness training for local administrations and health personnel on rehabilitation and assistive devices needs;

- MOPH to consult NDC, MMD and other resource people on rehabilitation policy and provisions.

\section{Inclusive education}

Education is a basic socio-economic human right and all children, including children with disabilities, have a right to education. The lack of proper education remains the key reasons for poverty and exclusion of all children from wider community affairs, both those with disabilities and the non-disabled. Lack of education and marketable vocational training for children and youth with disabilities results in an absolute lack of opportunities for further personal development. It diminishes their access to employment, other income generating activities and business development. 
A human rights development approach to disability has significant implications for the way in which education is provided for disabled people. Educationists tend to classify people with impairments according to kind of impairment. Disabled learners are then either placed in special schools or classes, or totally excluded from the educational opportunities.

Policy objectives for the education of disabled children and adults include education for all - to facilitate equal access of disabled people to education including community activities and equity in education provisions at all levels; to develop a single educational system for all, that will provide for the needs of all learners within an inclusive environment; to facilitate capacity buildings of all stakeholders, both institutional and human resources; and to provide educational provision including materials within an accessible environment.

All people living in Afghanistan should have equal access to education opportunities, regardless of their disability/ies. Every learner has her/his own interests, abilities and learning needs. Respect for diversity should be emphasized and promoted. Equity for learners with disabilities implies that additional support mechanisms such as appropriate technology, interpreters, Sign Language instruction for deaf learners are available within the inclusive learning environment. Early childhood intervention and learning provides children with disabilities with access to early intervention and socialization opportunities from an early age. Education will equip disabled people with the skills necessary to access the labor market.

The limited capacity of special schools even in the capital city, particularly in rural areas has resulted in the majority of learners outside the capital being excluded from education opportunities, because most regular schools do not facilitate integration. Disabled children and their parents have very little knowledge about their choices and the opportunities to have their children attend regular or special schools.

Free compulsory education should apply to all children of school-going age equally. Thus it should include children with disabilities, regardless of their disabilities. Where the general/regular school system does not meet the educational needs of children/students with severe disabilities they should have access to special classes or centres/schools. The aim of the education in these classes/schools should always be to prepare learners/students for education in the general system as soon as possible with close links with the local communities. Attention should particular be given to vocational training in all schools in order to provide learners/students with special needs.

Higher education institutions should also develop long life learning opportunities for disabled people and their families and link it with the general public education on disability. This will facilitate the development of the capacity of disabled people to participate more effectively in the economic development of their communities and the society as a whole; governance; and the monitoring of the equalization of opportunities for disabled people within their local communities, at regional and at central level.

\section{Key actions}

- Policy for special needs education should be endorsed and supported by Cabinet;

- Ministry of Education (MOE) integrates special needs education needs into national budget; 
- MOE develop strategy for Education for All (EFA) with officers appointed to encourage the inclusion of disabled children into regular schools as well as reporting on disability issues to MMD;

- Public awareness/education in regard to disability can be increased by use of media, radio, TV and TV sign language, magazine and newspaper articles etc.

- There is a need for close cooperation between the ministries of Education, Health and Martyrs and Disabled and Planning for better services for the disabled population with disabled themselves being part of this process.

- Planning for special education, integrated/inclusive education for disabled children young people and adults should be included as an integral part of the whole education planning/policy process for Afghanistan at this time.

- A department of "Special Needs" should exist and function actively within the ministry of Education in collaboration with the Ministry of Health and Ministry of Martyrs and Disabled.

- MoE should employ a number of disabled teachers in schools as well as in department of special education.

- On-going in-service training programmes should be developed by MOE in coordination and cooperation with universities and teachers training colleges - curriculum should include Paralympics component. In addition to providing specialist training on disability, higher education institutes can also conduct research and studies on various disability issues.

\section{Training and employment}

Disabled people have a right to decent work. Decent work is productive work in conditions of freedom, equity, security and human dignity. Disabled people have unique differences and abilities and they should have the right to choose what they want to do based on their abilities, not on their disabilities. They require the same educational, vocational training, employment and business development opportunities available to all. Some may require specialized support services, assistive devices or job modifications, but these are small investments compared to lifetimes of productivity and contribution

Vocational training and employment issues must be considered within the context of the full participation of disabled people in community life and within the macro context. Disabled people must also be regularly and actively involved in initiatives related to employment and training, not just as consumers but also as advocates, designers and providers of services. Services for employment support, including vocational training opportunities, must be accessible to all people without discrimination on the basis of gender, age, disability, religion, or political affiliation. All employment support initiatives for persons with disabilities must respond to a genuine market need

All disabled Afghans have the right to work, including the right to equal opportunity in the labour market (i.e. remuneration, safe, healthy and fair working conditions). In order to equalize opportunities for disabled people in Afghanistan, the obstacles to their social and 
occupational integration should be registered and appropriate measures taken to eliminate them progressively. Disabled women, who face compounded challenges in relation to mobility and other social issues, require specific vocational rehabilitation and employment policy strategies, in line with general government policy commitments to raise the social status and improve the living conditions of women in Afghanistan.

Government and employers must commit themselves to develop employment policies that address equity concerns and that positively discriminate in favor of disabled people in order to build representation of disabled people in the workforce.

\section{Key actions}

- Special Needs Education and Vocational Training should be integrated into development assistance programming by the MOE in cooperation with other ministries;

- Vocational training policy for youths and adults with disabilities should be developed by the MoE and Department of Vocational Educations;

- Department of human resources development should consult widely, on adult life skills and vocational training policy and planning for disabled people.

- The Government, should "ensure entry into productive employment, promote and develop creativity, dynamism and initiative, protect persons against unemployment, protect persons against occupational hazards, assist persons in their quest for satisfaction at work, for individual achievement and self-expression, and to achieve social, cultural and economic advancement."

- The Government should seek to introduce legislation that ensures the access of persons with disabilities to mainstream training and employment support opportunities, remove all legal barriers to participation of disabled people in the open labour market, and protect the rights of disabled people in employment.

- Close coordination between Government departments and other agencies is the key to the effectiveness of employment policy. In particular, the Ministry of Martyrs and Disabled, Ministry of Health, Ministry of Labour and Social Affairs, Ministry of Education, and Ministry of Rural Rehabilitation and Development, must liaise closely to plan, implement, monitor and evaluate coordinated strategies for disability employment support including vocational rehabilitation. The vocational rehabilitation and employment policy should "be based on the principle of equal opportunity between disabled workers and workers generally special positive measures aimed at effective equality of opportunity and treatment between disabled workers and other workers shall not be regarded as discriminating against other workers".

- Concerned Ministries must liaise closely with NGOs and Private Sector agencies to increase access of disabled people to mainstream training and employment opportunities.

- Ministry of Labour and Social Affairs, MMD, NDC, Ministry of Urban and City Planning, Ministry of Rural Rehabilitation Development and other stakeholders should work together to expand distribution of services to rural and regional areas, and stronger 
linkages between urban and rural strategies, must be a key aspect of the strategy on employment support for persons with disabilities.

- To ensure the sustainability of this policy, effective mechanisms, that include disabled people as key participants, must be in place to monitor the implementation of disability employment support policy. The Ministries of Martyrs and Disabled and Labour and Social Affairs should work closely in this area, in particular to ensure appropriate resources for permanent monitoring arrangements.

\section{Access to built environments and public transport}

The inclusion of disabled people into society necessitates free barriers environment that accommodates the diversity of needs, and enables the entire population to move around freely and unhindered and this includes accessible information system. For this reason, a clear and comprehensive policy on accessibility must be developed and be based on universal design ideals (Rapley, 2003).

Accessibility standards in Afghanistan are still neglected and the whole issue of barrier free society is still under discussion. There are a number of barriers, which prevent disabled people from enjoying equal opportunities with non-disabled people. For example: structural barriers in the built environment; inaccessible service points; inaccessible entrances; poor town planning; and poor interior design. It must be emphasized that barriers also include communication barriers i.e. oral language is a barrier for sign language users.

Inaccessibility to the built environment is still a major barrier, which prevents disabled people from actively participating in social and economic activities. A building code having requirements for access for disabled people is urgently needed. Universal design approaches that provide for greater accessibility for all people have proven to benefit not only disabled people but also many other sectors within the society including older people, pregnant women and parents with young children. Physical barriers prevent full participation and reduce the economic and social contribution and productivity of disabled people. Investments in the removal and prevention of architectural and design barriers are increasingly being justified on economic grounds in many developed economies, particularly in areas most critical to social and economic participation (e.g. transport, housing, education, employment, health care, government, religious activities, commerce, leisure and recreation). It is important to note that not only facilities but also services should be accessible in their entirety. In this connection listening to opinions of disabled people should be an important part of a staff training curriculum and the various services.

Disabled people have rights to identify and take part in removing the disabling barriers aginst their inclusion. This can best be done through their NGOs. For policy planning purposes, it is important to know what provisions already exist and made accessible for disabled people and what improvement can be made on existing ones. Equally important is to know what new provisions which should be be made available.

Provisions for free barriers soceity include policies such as existing legislation on accessibility, local regulation, international statements etc as well as accesible services such as mentioned [1]

earlier. Services include those relating to public use such as education, transport, 
employment, etc and those pertinent to private use such as home adaptation, car adaptation etc.

At this point in time while Afghanistan is due to have its first general election, its is very important that disabled people take active part in the process and accessible provisions be made to enbale this to happen.

\section{Key actions.}

- Ministry of Public Works (MOPW) to develop technical specifications on access engineering and design requirements in consultation with MMD, NDC, and other agencies;

- MOPW to revise existing National Building Code (NBC) in consultation with the MMD, the NDC and other related agencies.

- Ministry of Transport revise transportation law in consultation with the MMD, the NDC and other related agencies.

- MOPW and MMD collaborate on public consultations on the review of NBC and transport law to ensure inputs by disabled people;

- MMD in collaboration with NDC to conduct an awareness-training workshop on disability access issues for MOPW. Technical documents can be translated and disseminated widely. The whole issue of accessibility could also be included in the curriculum of higher technical education.

\section{Access to information, communications, and assistive technologies}

Effort needs to be directed to the development and dissemination of Sign Language, Braille, finger Braille and other forms of communication. Without access to such forms of communication, people with visual and/or hearing impairments may be deprived of the basic human right to language and communication in their everyday lives. Afghan sign language should be further developed and the sign language dictionary should be extended. Communication tools also include the provision of training on best coping skills for families with disabled members, especially those cases with severe disability or intellectual impairments.

Assistive devices are essential for improving the mobility of people, the overall quality of life and in ensuring greater independence. For example mobility support for the blind can greatly enhance their independence. The greatest challenge lies in the rural areas where mobility issues are most difficult to address and assistive devices are most difficult to deliver because of the lack of services and follow-up to train people in their uses. The CBR approach however, works best in such areas reaching out for disabled people and their families.

Research should be the basis for the design and provision of communication and assistive technology support for disabled people. Individual needs should be carefully considered. Technical devices should be supported by disability sector with law to make them affordable to everybody. 
THE COMPREHENSIVE NATIONAL DISABILITY POLICY IN AFGHANISTAN Page 29 of 42

\section{Key actions}

- MOPH in coordination with MMD to collect data on demand for assistive services;

- MOPH to review skills and human resources necessary to develop appropriate assistive devices;

- Assistive devices to be integrated into the national rehabilitation policy and included as "line item" in MOPH budget.

- MMD with Ministry of Information and Culture to design best communication tools for disabled people and propose strategies for making them available for various disabled people.

- MMD together with concerned parties facilitate the election process for disabled people and provide information necessary for disabled people to nominate disabled candidates and to take part in various national, regional and local elections.

\section{National coordination mechanism}

The coordination of services minimizes the likelihood of duplication and is more likely to ensure that services and programmes are more effectively delivered and strategic alliances between agencies are more likely to be developed and synergies achieved. This requires the sharing of information and the establishment of communication channels between government ministries and departments as well as the establishment of alliances and working partnerships with local administrations and non-governmental organizations. As an outputs oriented mechanism, national coordination also helps the smooth development of participatory policies and their proper implementation linking policy with action across all government programmes.

Therefore, an independent body tasked with the coordination of the disability sector should be set up to ensure services are delivered in an effective and coordinated way. The existing National Disability Commission can be further strengthened by improving structure and the mechanism for implementation of its tasks. National coordination should rely on facts gathered from surveys, research, and needs assessment.

The Government should establish a Disability Officer position as its focal point for disability policy and services. An effective working partnership between Government and NGOs will not only improve coordination but will also be an important step that will ultimately lead to the greater protection of human rights and the building of a more inclusive society.

\section{Key areas}

- MMD and NDC to make copies of this Comprehensive National Disability Policy available to all community and other interest groups;

- MMD to report regularly (i.e. annually) on progress in implementation of the Comprehensive National Policy on Disability;

- NDC reviews its charter to emphasize national coordination requirements and benefits; 
- NDC develops policy monitoring arrangements.

\section{Preconditions for the implementation of this policy}

As mentioned earlier to achieve the objectives set out for this policy, considerable capacity building has to be carried out not only for government agencies but also for wider community organizations including disabled people groups. The following are being recognized as prerequisite for a smooth implementation of this Policy.

Poverty alleviation:

Capability poverty is the most prevalent form of poverty and this can be both a cause and consequence of disability. Poverty and disability reinforce one another, contributing to increased vulnerability and exclusion. Poor nutrition, dangerous working and poor living conditions, limited access to vaccination training, lack of health and maternity care, poor hygiene, bad sanitation, inadequate information about the causes of impairments, and civil conflicts are factors responsible for disability. Many of these causes are preventable. Disability in turn exacerbates poverty, by diminishing access to means of livelihood, increasing isolation from the marketplace and economic difficulties. This affects not just the individual but often the entire family and local community.

The Department of Statistics should publish poverty/vulnerability data from their census and make it available for the public as well as for policy makers and service providers. Further, MMD should work with micro-credit advisers and lenders to develop information packs for disabled people on income generation and micro-credit. Specialist schemes for small business enterprise projects for self employment targeting disabled people with necessary training workshops in remote areas should be developed. Finally, MMD together with MLSA, NDC and other disabled people should review the existing labor laws.

Research and data collection:

For proper implementation of this policy and other disability related legislations, the government should be assigned the responsibility for collecting data and carrying out a census on disability. The national census should include a question on disability. Access to accurate and regularly updated information is vital for advocacy, and for the purposes of planning and implementation of services for disabled people.

Information empowers people, and a better-informed society will also lead to greater understanding, reduce discrimination and enhance tolerance and support for the full participation of disabled people within all aspects of community life. Families and communities need information on disability as well as information on prevalence in order to increase public awareness and understanding of disability concerns and issues. There needs to be collaboration between public libraries, information centers and organizations of disabled people both nationally and internationally to increase the availability of information in different forms, and mechanisms need to be explored to make new technology more available to disabled people so that they can access information and communicate locally and globally.

The Office of Statistics can play an important role in providing basic data on disability and this could be easily gathered through the inclusion of disability issues in their surveys and census. 
MMD should therefore coordinate data obtained from departments of Statistics, Education and Health and publish this information and ensure that it is included in the national disability profiles and made available to local governments and other central government ministries. This should be done in collaboration with NDC to ensure that disabled people are consulted on information/data requirements, their collection and analysis and outputs of research productions. Definition of disability is important and greatly influences any data collection process on disability and subsequent provisions.

Boosting public awareness:

When the wider community is aware of the human rights and needs of disabled people, then environmental and attitudinal barriers are more likely to be dismantled and the community is made more accessible and inclusive of disabled people, their rights are more likely to be protected, their abilities will be valued, their diversity and interdependence will be recognized and they are more likely to be integrated into daily life. Awareness of fundamental human rights of all people is a cornerstone to achieving an inclusive society.

MDD should therefore gather and collate data from key government agencies and disseminate them to local communities and central government ministries and departments. Further MDD and NDC should hold a series of "rights and disability" workshops for disabled people, especially in rural areas.

\section{Commitment}

This policy provides a framework to address the rights of disabled people.

It has been developed in consultation with a wide range of individuals, government agencies, non-governmental organizations and individuals in the country.

In line with the Government's support for various international, regional and national human rights statements, the implementation of this policy will bring about the full inclusion of disabled people in the day-to-day activities and decision making of communities throughout the country. As previously cited, this Policy operates within the framework of Afghan National Constitution and it is in line with the UN Standards Rules, the BMF, the new proposed disability convention, and other human rights conventions including the Convention on the Rights of the Child.

\section{CHAPTER FIVE}

\section{IMPLEMENTATION OF POLICY}

To improve the quality of life for disabled people and enhance their individual and collective opportunity for self empowerment, disabling barriers have to be identified and removed. A comprehensive package of measures including political ones should be put in place to combat discriminatory practices against disabled people.

However, political measures alone including legislations are not sufficient tools to ensure the rights of disabled people. They should be combined with other socio economic and cultural 
measures to bring about the aspired social change in society. Nonetheless, if correctly administered, legislation does provide an important enforceable legal support against discriminatory practices. Therefore, to protect and promote the rights of disabled people, there is a need to establish specialized legal institutions and develop mechanisms to ensure proper implementation.

Future legislations on disability must be based on the principles enshrined in the National Constitution. Disability sector must get involved in discussion of future proposed legislation with focus on inter-sectoral co-operation amongst all stakeholders. Future legislations must ensure equality, non-discrimination and protection for disabled people. Existing disability legislation must be scrutinized for compliance with the constitutional principles.

To ensure the coordination and implementation of the Comprehensive National Disability Policy into government policies, it is recommended to link the existing National Disability Commission with government structure by locating NDC under the Vice President for Constitutional Commission. The purpose of this location is to ensure that NDC has sufficient access to all government departments and to ensure that it impacts positively on all government legislation, policies and programmes. The NDC will work closely with MMD and all other stakeholders.

The functions of National Disability Commission include: to facilitate, coordinate and monitor the implementation of the Comprehensive National Disability Policy; provide a link between Government and civil society via various disabled people organizations; develop a management system for the coordination of disability planning, implementation and monitoring in the various departments; provide advice to the various government departments on disability matters; ensure wide public education, as well as capacity building for the disability movement and government departments to implement this Policy; facilitate the development of legislation; facilitate and coordinate public awareness programmes aimed at changing fundamental prejudices in society; facilitate budget analyses to identify whether sufficient resources are targeted towards disability, and particularly towards the integration and empowerment of disabled people; and facilitate financial resources in support of the implementation of this Policy.

The Comprehensive Disability Policy in Afghanistan can best be implemented when integrated into government policies and programs under the National Development Framework. All ministries, especially line ministries in practical terms, should support strategies designed to ensure proper implementation of this policy. It is essential that municipalities, local government and all other stakeholders develop implementation plans at local level to realize the strategies outlined in this policy. Information sharing must be accessible to partners' especially disabled people.

\section{CHAPTER SIX}

\section{MONITORING OF POLICY}

Monitoring is an essential element in the upholding of human rights. Monitoring can be used as a corrective tool against the violated rights of disabled people. It can also be used to 
THE COMPREHENSIVE NATIONAL DISABILITY POLICY IN AFGHANISTAN $\quad$ Page 33 of 42

measure trends and patterns of discrimination.

While all monitoring structures in Afghanistan should include the monitoring of the rights of disabled people in their mandates, the National Disability Commission will have a special responsibility for this task.

The NDC, being situated at a central location within Government, and having the responsibility for co-coordinating the implementation of the Comprehensive National Disability Policy, will clearly be the key structure within the Government to monitor not only the implementation process, but also its impact and the human rights of disabled people in general. Key Government departments primarily MMD, will also have an essential monitoring role.

The objective is to establish a system of monitoring at all levels, in the private, as well as all spheres of government and in the public sector. It must be horizontal and vertical (between government and citizens, and between citizen and citizen).

The scope of monitoring should encompass the full society and at all levels including local community. However, particular groups should be targeted as cited earlier in special target groups.

Formal monitoring must be guided by key performance indicators. It must, in other words, be measured so that results can be assessed. Monitoring must be done in collaboration with other stakeholders including disabled people using proper research and evaluation practices.

Effective Monitoring is that which is based on research practices and accurate data. In this connection, it is important to develop the agenda for disability research and use of proper terminology on disability. A systematic review of all national laws and policies is an important part of the monitoring exercise. Dissemination and coordination of the monitoring process and its findings to all partners in accessible format is of prime importance.

\section{RECOMMENDATIONS}

This Comprehensive National Disability Policy and its recommendations are the result of collective effort between all disability stakeholders in Afghanistan including the international community. A balance between outsiders' culture and their influence and the local norms and values have been maintained by the active participation of Afghan disability experts as well as disabled Afghans themselves. As a joint owner of this policy, MMD encouraged disabled Afghans to get involved actively in all stages of policy development as equal partner and as owner of this policy.

The role of international collaboration in supporting the disability sector in Afghanistan including this policy is fundamental. Throughout the process, international support to the implementation of this policy should focus on building confidence and local solutions to local problems by encouraging community based interventions where local resources and skills are utilized to the maximum level possible. This will ultimately help the promotion of models of 
good governance in Afghanistan's own projects and interventions including the level of local participation, transparency, accountability, and the rule of law.

The disability sector in Afghanistan has to come of age if it is ever to meet the growing needs of disabled people as well as societal expectations from a human rights perspective. Given the absence of a comprehensive disabled people's strategy in Afghanistan, long term objectives for this policy could focus on: improving disabled peoples' quality of life through the enhancement of life chances and life choices; promoting inclusive practices within intended rehabilitation interventions; facilitating the emancipation of disabled people in society at both policy and practice levels.

For this to happen, it is important to endorse a development approach to disability which looks at disability as a human rights issue that need to be integrated into wider community development initiatives with participatory planning based on research and assessment, thus the need for a research agenda on disability. It is equally important to develop proper terminology and definitions (for both the administration of disability programmes and the collection of data) and the use of politically correct language describing disabling conditions, human rights and gender balance.

The recommended key actions for each priority area cited in chapter four (policy guidelines) are the most important to the implementation of this policy and to the disability sector in general. These key actions have been agreed upon and supported by the disabled community and other stakeholders in Afghanistan.

However, a principal recommendation that emerged from this policy paper deals with MMD's future role as coordinator, supervisor and regulator of disability issues in the country. A more general recommendation requests that MMD in collaboration with the National Disability Commission, and the MoPH, MoE, MoLSA, MoWA and other line ministries and stakeholders facilitate the process for developing national guidelines of inter-sectoral responsibilities in each of the policy areas cited in this document including necessary co-ordination of needed disability services in Afghanistan. Equally important is the role of MMD, Ministry of justice, and the above agencies in investigating the feasibility of developing disability specific legislations.

At this stage, it is very important that the government edorse this policy and include it into the National Development Framework as a priority cross cutting issue. Hence, it should be integrated into all government programmes and initiatives with a national budget allocation.

The following general recommendations substantiate and complement those cited in chapter four. These relate to cross cutting measures on disability prevention, rehabilitation, education and awareness raising, employment, accessibility, and coordination. Having said that, it should also be recognized that disabled people also require specialist assistance in the area of housing, personal care, and financial benefits to name but few. Specific guidelines in these areas should be developed accordingly.

1. In terms of prevention, the Ministry of Public Health, MMD, NDC and other stakeholders should develop inter- sectoral impairment prevention strategies that will set national norms and minimum standards for the prevention of disabling conditions and disability discrimination. Aspects that should receive attention include referral systems; the inclusion of training programmes; key performance indicators to determine (measure) the effectiveness of 
disability prevention programmes; national norms and standards for focused and participatory research in disability prevention, and the development of clear inter-sectoral mechanisms.

Many of the causes of impairments and injuries are preventable through developing safe living/work place environments, improving safety measures in the community, including road safety, which can decrease disabilities associated with traffic accidents. Similarly, improving immunization and eliminating malnutrition and iodine deficiencies and good awareness of balanced diet and other daily practices to improve health can also decrease the incidence of certain types of disabilities.

2. Increasing public education and awareness is fundamental for the success of this policy. The National Disability Commission, MMD, and other stakeholders, should develop a medium and long term disability awareness strategy that will include, amongst other things: national guidelines for the use of disability sensitive terminology and uniform disability related definitions; highlighting the role of both the public and private media; raising awareness of disability as a human rights and development issue, and criteria for the development of sectoral disability awareness projects notably regarding land mines issues.

3. The Ministry of Public Health must work closely with the MMD, the NDC, and other concerned agencies to develop a comprehensive national rehabilitation policy that targets all disabled people and their families as well as those at risk. Appropriate, accessible and affordable health services at primary, secondary and tertiary level. Such services should include family medicine and community home care, in-patient, physical and rehabilitation services should be offered in co-operation with NGOs and Disabled people Organizations (DPOs). A community based rehabilitation approach can be especially useful to reach cases at home and in rural areas. It is believed that such an approach will increase access to comprehensive, extensive medical and mental health services. The medical needs of disabled people including treatment and assistive devices should be part of the Health care package. Further, a coordinated plan for training of health care professionals should be developed by the above agencies.

4. The Ministry of Education, the Ministry of Higher Education, and vocational education, and the MMD should collaborate together to develop policy that facilitates equal access to education and the development of a single education system that will meet the needs of all learners within an inclusive environment. This includes a plan of action for addressing the high illiteracy rate among disabled people and initiates immediate education programs for all age groups. Public education is also important for changing attitudes towards disability.

5. The ministry of Labour and Social Affairs, the MMD, the NDC and other agencies should develop a comprehensive national employment strategy to address the employment needs of disabled people. In so doing, creating conditions to broaden the range of employment and economic development options for disabled people in order to narrow the income gap between non-disabled and disabled people. This should include early return to work programmes as well as sheltered employment and public, self and private options of employment.

6. Barrier free access to built environment and transports is a precondition for any progress on the implementation of this policy as well as for inclusion of disabled people into society, especially into the economy. Ministry of Martyrs and Disabled, joint with Ministry of High 
Education, Ministry of Labour and Social Affairs, and National Disability Commission must promote the diffusion of technical knowledge about accessibility, the adaptation of them to the Afghan reality and the integration of accessibility issues in technical higher education curricula. Ministry of Martyrs and Disabled joint with Ministry of Public Works and Ministry of Transport and other stakeholders, must develop a law to decide general principles, rules, sanctions and incentives with regard to barrier-free access to built environment including working place, buildings and transports. A technical guideline should also be attached to the law and be made accessible to disabled people in appropriate format.

Barrier free access also includes accessible communications tools and assistive technology. The Ministry of Information and Culture, MMD, MoE, NDC, and other stakeholders including the deaf community, must facilitate a process for the development of a national strategy and programme of action for the development of Sign Language and mechanisms that makes it works. Further, the above agencies should work together to develop strategy to support the development of communication technology for other disabled people such as blind and those with severe physical and intellectual disabilities.

7. It is also recommended that Electoral Commission and the Ministry of Interior Affairs, in consultation with the Constitutional Commission, NDC, and MMD at all levels facilitate a process to develop national guidelines and minimum standards for communication during national, provincial and local government elections. In this process as in others access to information in proper format to suit different kind of disabilities is of prime importance.

At the global level, grass root action should be promoted with the central role given to disabled people groups and organizations. Disabled people and their organizations have a central role to play in the rebuilding of the Afghan society including its democratic systems. Community based approach to the development and implementation of disability policy should be utilized. Community based support for people with severe mental disabilities and other marginalized and invisible disabled groups can be very effective and cost effective.

8. All statistics and research on disability should be coordinated by MMD in close collaboration with Department of Statistics, NDC, MoPH, MoE, MoLSA, MoWA, and other stakeholders including disabled people organizations. Handling disability data collection, analysis and dissemination requires technical support by the above agencies.

9. Coordination and monitoring mechanisms are necessary at all levels with MMD, and NDC, taking leading role. A new charter for NDC focusing on the coordination and monitoring of policy should be developed in collaboration with all disability stakeholders. 
Afghan Constitution (1980) The Law of the Rights of the Revolutions Injured, Disabled anc Dependents of Martyrs, ratified in 1982.

Afghan Constitution (1987) Chapter Three on Citizenship, Basic Rights, Freedoms, and Duties of Citizens.

\section{WWW.AFGHAN-WEB.COM/HISTORYICONST/CONST1987}

Afghan Constitution (1990) Chapter Three on Citizenship, Basic Rights, Freedoms, and Duties of Citizens.

\section{WWW.AFGHAN-WEB.COM/HISTORYICONST/CONST1990}

Afghan Draft Constitution (2003) Article Fifty Three, Chapter Two Fundamental Rights anc Duties of Citizens. WMW.CONSTITUTION-AFG.COM

Agnew, M (2003) Labour market information Survey. International Rescue Committee (IRC) ir cooperation with Ministry of Labour and Social Affairs..

BMF (2003) Biwako Millennium Framework for Action Towards an Inclusive, Barriers Free anc Rights Based Society for Persons with Disabilities in Asia and the Pacific (BMF). Unitec Nations Economic and Social Council, Otsu City, Shiga, Japan.

Coleridge, P. (2002), 'Community Based Rehabilitation in a Complex Emergency: Study o' Afghanistan', in M. Thomas, and M.J. Thomas (eds), Selected Readings in CBR . Series 2: Disability and Rehabilitation Issues in South Asia, National Printing Press Bangalore, pp. 35-49.

DSI (2001) Comprehensive disability Policy Framework for Kosovo. SDI, Denmark http://www.disability.dk/site/viewdoc.php?doc_id $=300$

Miles, M (2002) Formal and Informal Disability Resources for Afghan Reconstruction. Work Quarterly Vol. 23, pp. 945-959.

Ministry of Education (2002) policy for the rehabilitation and development of education ir Afghanistan.

Ministry of Labour and Social Affairs (2003) internal regulations for national employment.

Ministry of Martyrs and Disabled (2003) Policy proposal for a commission to protect the rights of war disabled people. February 2003.

Ministry of Public Health (2003) Interim health strategy 2002-2003.

Ministry of Public Health (2003) A basic package of health services for Afghanistan.

MLSR (1997) White paper on National Policy on disability. Republic of Namibia Ministry o Lands, Resettlement and http://www.gladnet.org/infobase/Files/280.htm

Rehabilitation (MLSR)

MSD (2001) Implementation of the New Zealand Disability Strategy. Ministry of Social Development (MSD). 
Nagata, K (2003) Gender and Disability in the Arab Region: the challenges in the New Millennium. Asia Pacific Disability Rehabilitation Journal, Vol 14, No 1, 2003.

Oliver, M. \& Barnes, C. 1998. Disabled people and Social Policy: From Exclusion to Inclusion. London: Longman.

Rapley, C (2003) Reconsidering the disability Dimension in Development Cooperation Activities; building national capacities for full participation and equality. Regional Workshop towards a Comprehensive and Integral International Convention on Protection and Promotion of the Rights and Dignity of Persons with Disabilities. October 14-17, UNESCAP, Bangkok.

UN (1994) The Standard Rules on Equalization of opportunities for Persons with Disabilities. NY, UN.

The White Paper (1997) Integrated National Disability Strategy Paper. Office of the Deputy President, South Africa. www.gladnet.org/infobase/Files/319.htm

UNDP (1997) Poverty Eradication and Community Empowerment. UNDP, Afghanistan.

UNESCAP (2003) New International Convention to Protect and Promote the Rights of Persons with Disabilities - draft. UNESCAP, Bangkok

Wardak, A and Turmusani, M (2003) Development agenda in Afghanistan: disability model. Japanese Journal of Trade and Industry, November/December 2003.

Wardak, A, Faiz IM, and Turmusani, M (2003) Disability policy development in Afghanistan: towards barriers free society. UNESCAP, Bangkok.

WHO (2001) International Classification of Functioning, Disability and Health. WHO, Geneva.

\section{APPENDIX (1)}

\section{LIST OF EXPERTS}

[3]

\section{Chairperson}

HE Mr A. Wardak, Minister of Martyrs and Disabled

\section{Honorary participants}

HE Mr Mohammad Qanooni, Minister of Education.

HE Dr Sohaila Sidiqi, Minister of Public Health.

HE Mrs Margherita Boniver, Italian Deputy Minister of Foreign Affairs.

HE Domenico Giorgi, Ambassador of Italy, Kabul 


\section{Technical team}

Dr Majid Turmusani, Chief Policy Advisor, Ministry of Martyrs and Disabled Ms Kay Nagata, First Social Affairs Officer, UNESCAP

\section{Core group}

\section{[4]}

Mr Abdul Khaliq Zazai, Political Secretary to Minister of Martyrs and Disabled. Haj Abdulrahiman, Leader of Disabled Community

Ms Nafisa Sultani., Leader of Disabled Women

Mr Fiaz Ihsan, Head of Afghan National Association of the Blind

Mr Karim Khan, Head of Afghan National Association of the Deaf

General Noor Mohammad, Head of the National Disability Commission, NDC Mr Qaseem Wardak, Secretary to Minister for NDC

Ms Meriel Carboni, Donor Relations, International Assistance Mission

Ms Margret Knill, Blind School, International Assistance Mission

Mr Alfred Buachret, Director, SERVE

Ms Karin Coats, Disability Advisor, SERVE

Ms Helen Hensen, SERVE

Ms Barebel Parples, SERVE

Mr Alberto Cairo, International Committee for Red Cross (ICRC)

Ms Pualine Fowlei, Afghan Amputees Bicycle Rehabilitation and Recreation

Mr Richard Pinder, Handicap International

Mr Andrea Pascarelli, Italian Cooperation

Ms Simona, Lanzoni, Italian Civil Volunteer Group

Mr Shaheen, Himat, Afghan National Association of the Blind

Dr Abdul Baseer, Afghan Amputees Bicycle Rehabilitation and Recreation

\section{Participant experts}

Ms Humairah Hanif, Office of President Karzai

Mr Abdulmalik Kamawi, National Constitution Commission

Dr. Darwish Tawana, Ministry of Public Health, Kabul

Mr. Alim Aimaq, Ministry of Labour and Social Affairs, Kabul

Ms Nahid Zarsanga, Ministry of Women Affairs, Kabul

Mr A Haidari, Hearing Impaired Foundation Afghanistan

Syawash Batoor, Hearing Impaired Foundation Afghanistan

Mr Omara khan, Afghan Amputees Bicycle Rehabilitation and Recreation

Abdul.Wali Shahamat, Social Development Rehabilitation Organization, Kabul

Abdurraheem Raeq, National Disability Commission, Kabul

Aqa gul Nikmal, National Union for the Protection of War Victims and War Shatters of Afghanistan (VNA)

Amina Jagdalak, National Afghan Disabled Women Association (NADWA)

Mr Amir Mahmood Panjshiri, National Afghans Disabled Association (NADA)

Mr llias Haqmal, National Afghans Disabled Association

Mr Hamid Lami, National Afghans Disabled Association 
Dr Ahmad Shadoli, WHO.

Ms Andreana Zarraluqui, CDAP

Ms Sylvy Goria, CDAP

Mr Abdul Hamid Ahmad Zai - CDAP

Mr Baheer Wardak, ILO

Mr Andrea Pollastri, Italian Cooperation;

Ms Susan Helseth, UNICEF

Mr leo Iwasaki, International Supporters Association for Reconstruction of Afghanistan (ISARA)

Ms Hiroko Ikeda, ISARA

Ms Sarah Kamal, Humanitarian Aid for Women and Children Afghanistan

Ms Fiona Gall, Sandy Gall Appeal for Afghanistan (SGAA)

Ms Mary MacKain, PARSA

Mr Francois Large, CARITAS

Ms Judy Thorin, Physiotherapy Institute

Mr Marti Pritchard, International Assistance Mission

Mr Najmuddin Suhail, ICRC, Kabul,

\section{Experts who made comments on the draft}

Dr Sheila Wirz, Centre for International Child Health, ICH, University College London, UK

Dr Devva Kasnitz, University of California, Berkeley

Dr Filomena Pietrantonio, CIRPS, University of Rome, Italy

Dr Sophie Mitra, Rutgers University, USA

Ms Meriel Carboni, International Assistance Mission, Afghanistan

Ms Anja De Greve, Platform for Disability and Development Co-operation, Belgium

Professor William Boyce, Queens University, Canada

Professor Akiie Ninomiya, Asia Pacific Centre on Disability, Thailand

Mr Peter Coleridge, ILO, Kenya

Dr Andrea Micangeli, CIRPS, University or Rome, Italy

Mr Clinton Rapley, Associates for International Management Services NY, USA

Dr Patrick Devlieger, University of Leuven, Belgium

Akemi Bando, Japan International Cooperation Agency, JICA

Brother Andrew De Carpentier, Holy Land Institute for the Deaf, Jordan

\section{APPRENDIX (2)}

\section{LIST OF ABBREVIATIONS}

AABRAR: Afghan Amputee Bicycle for Rehabilitation and Recreation

ANAB: $\quad$ Afghan National Association of the Blind

ANAD: $\quad$ Afghan National Association of the Deaf

BMF: $\quad$ Biwako Millennium Framework for Action towards an Inclusive,

Barrier-free and Rights-based Society for Persons with Disabilities in the Asia 
and Pacific region

CBR: $\quad$ Community Based Rehabilitation

CDAP: $\quad$ Comprehensive Disabled Afghan Programme

CDC: $\quad$ Centre for Disease Control, USA

- CEDAW: Convention on the Elimination of All forms of Discriminations against Women

CRC: $\quad$ Convention for the Rights of the Child

DPOs: 'Disabled People Organizations

DSA: Disabled Shura Afghanistan

GAD: $\quad$ Gender and Development

HIFA: Hearing Impaired Foundation of Afghanistan

IAM: International Assistance Mission

ICRC: International Committee for Red Cross

ILO: International Labor Organization

INGOs: International Non Governmental Organizations

IRC: International Rescue Committee

ISESCO: Islamic Educational, Scientific, and Cultural Organization

MMD: $\quad$ Ministry of Martyrs and disabled

MOE: $\quad$ Ministry of Education

MOLSA: $\quad$ Ministry of Labour and Social Affairs

MOPH: $\quad$ Ministry of Public Health

MOPW: $\quad$ Ministry of Public Works

MOWA: $\quad$ Ministry of Women Affairs

NADWA: National Association of Disabled Women in Afghanistan

NBC: National Building Code

NDB: $\quad$ National Development Budget

NDC: National Disability Commission

NDF: $\quad$ National Development Framework

NGOs: $\quad$ Non Governmental Organizations Pacific

SERVE: $\quad$ Serving Emergency for Rehabilitation of Vulnerable

UNDP: $\quad$ United Nations Development Programme

UNESCAP: United Nations Economic and Social Commission for Asia and

UNHCR: $\quad$ United Nations High Commission for Refugees

UNICEF: United Nations Children's Fund

UNOPS: $\quad$ United Nations Office for Project Service

WHO: World Health Organization 


\section{WPACDP: World Programme of Action Concerning Disabled Persons}

\section{[1]}

This includes transport (streets, bus, airport, and parking places, etc); schools (accessible building, equiped classes,); public toilets; parks, rest places etc; cultural, touristic and recretional places (theatre, sports centres etc); hospitals, medical centres, etc; public building where services are provided such as ministries, UN buildings, INGOs, local admin, police department, etc; market place, such as banks, barber shops, etc; religious places, such as mosque, etc; workplaces, vocational training etc; and others.

\section{2} These relate to personal use at home including adapted home, kitchen, toilet, etc; adapted car, parking places bavement, easy signs and directions and others. Government subsidies can greatly improve these provisions.

${ }^{3}$ More than 220 participant experts took part in the development of this policy on regular basis since the inception of Task Force on Disability in Feb 2003. The total number of participants who attended specialist seminars and workshops are 179 persons representing 50 agencies including all disability NGOs (local and international); related UN agencies; disabled people organizations; and government representatives from Ministry of Health, Education, Labour and Social Affairs, Women Affairs, and MMD central office as well as their offices in Bamyan, Mazar, Jalalabad, Ghazni, Kandahar, Hilmand, Hirat and Kabul. The remaining are individuals who belong to unregistered organizations from the above provinces such as disabled people groups.

\footnotetext{
4

Members of this group have been active in the process of policy development and regularly attended meetings organized by Task Force on Disability. They often assumed technical responsibility including facilitation of group meetings, reporting and on occasions making presentations.
} 